\title{
Change of Hydrological Regime and Water Quality Due to Reduced Wastewater Discharged into Surface Waters
}

\author{
Věra Hubačíková1*, Jozefína Pokrývková², Jana Marková ${ }^{3}$ \\ 'Department of Applied and Landscape Ecology, Faculty of AgriSciences, Mendel University, Brno, Czech Republic \\ ${ }^{2}$ Department of Water Resources and Environmental Engineering, Slovak University of Agriculture, Nitra, Slovakia \\ ${ }^{3}$ Department of Landscape Management, Faculty of Forestry and Wood Technology, \\ Mendel University, Brno, Czech Republic
}

Received: 4 December 2018

Accepted: 31 July 2019

\begin{abstract}
The trend of decentralized treatment of wastewater from urbanized areas is becoming more and more topical. Sewage is discharged to a sewage treatment plant, and rainwater runoff from paved areas is drained into a watercourse or is absorbed or evaporates to enter the natural cycle of water. This is the case as shown in our research in monitoring the changes in flow rate and changes in water quality in the millrace. After construction of vacuum sewerage systems in the villages of Zbýšov and HostěrádkyRešov, the households were gradually connected to the sewerage system, thus reducing the flow of water in the millrace. To monitor changes in water quality, regular measurements were made on 5 profiles and water was sampled, analyzed and evaluated. The results were then compared with the standards set out in the valid legislation of the Czech Republic. Research showed that the water quality of surface water can be improved by reducing the burden of discharged sewage water into the flow. However, reduced flow rates in the flow can lead to higher concentrations of pollutants. This can also be caused in the long term by agricultural activities in the area of interest.
\end{abstract}

Keywords: sewerage, watercourse, pollutants, flow of water

\section{Introduction}

Wastewater discharge and treatment is today one of the priorities of strategic planning within the South Moravian Region and the whole of the Czech Republic. Wastewater drainage and its subsequent cleaning are basically resolved with respect to the adoption

*e-mail: vera.hubacikova@mendelu.cz of EU legislative conditions in the Czech Republic for municipalities with more than 2000 inhabitants. Attention is now being directed to municipalities with fewer inhabitants. Existing wastewater treatment plants are currently focusing mainly on the removal of phosphorus from wastewater. Significant amounts of phosphorus in wastewater and its insufficient removal by treatment plants causes problems with eutrophication of surface waters, especially in tanks [1]. The problem of eutrophication and increased concentrations of pollution in tanks has also multiplied in recent years due to high 
temperatures and droughts, where minimal inflows into tanks and increased evaporation cause low water levels in reservoirs and consequently increased concentrations of pollutants. The increasing share of hard surfaces and a growing number of residents in rural landscapes in the last decade brings interference with the natural circulation of water and chemical components. Also, intensification of agriculture, use of mineral fertilizers, chemical weed control, pest management and natural chemical processes on land [2]. The circulation of water and chemical components in rural landscapes has been seriously disrupted in recent decades as a result of growing civilization, including intensification of agriculture, the application of mineral fertilizers, and chemical weed and pest control [3]. Many types of pollutants enter surface waters from urban, industrial, and agricultural lands. Due to the use of large areas of arable land, agricultural activity is a major source of nutrients and harmful chemicals [4].

It is not rare when a situation arises where the only source of surface water is the effluent from WWTPs. In 2010, in the South Moravian Region alone, a total of 53.542 million $\mathrm{m}^{3}$ of treated water was discharged from WWTPs to surface waters [5]. This considerable amount deserves attention, especially at a time when the importance of these waters for the supply of streams and reservoirs is increasing, and with the increasing number of connected inhabitants in the new WWTP the volume of these waters will increase slightly.

Newly constructed sewerage systems are now built only for sewage drainage, and rainwater is dealt with separately. The rainwater management (RWM) concept in an urbanized river basin reproduces as closely as possible the natural outflow characteristics of a site prior to urbanization [6]. So-called decentralized drainage is the basis of the RWM, the essence of which is to deal with the precipitation runoff at the site of its origin and return it to the natural cycle of water. In the narrowest sense, nature-friendly measures and equipment RWM are those which promote evaporation, infiltration and slow runoff into the local water cycle. In a broader sense, this includes equipment that at least in some ways contributes to the maintenance of the natural water cycle and to the protection of watercourses, such as accumulation and use of rainwater or retention, and regulated (delayed) drainage into the sewer system $[7,8]$. This sewage treatment solution, where sewage is conducted to WWTP through the sewerage system and rainwater is addressed separately in a decentralized manner, applies to new housing developments especially in newly built parts of urban areas.

When dealing with the connection of older settlements, especially small municipalities (under 2,000 inhabitants), only sewerage is addressed, and rainwater is basically not dealt with at all, its disposal being left up to the individual owner of a particular property.

The present research deals with municipalities in the South Moravian Region, where sewerage was built and connected to the WWTP. In previous years, wastewater from septic tanks and cesspits was drained along with rainwater via the same sewage system into the bed of the former millrace. Today the tributary flow from these facilities in the village to the millrace is minimal, and virtually zero in the dry period.

As the research cited below and some of the experiences and research from neighbouring countries shows, rainwater management can also bring unexpected effects and impact the landscape or the quality of surface waters $[9,10]$. There is, therefore, an ever-increasing need to find the most efficient ways to manage water in the landscape. Both with respect to water obtained from precipitation in the open countryside as with water from developed areas, mainly with older deveopments.

To monitor the change of the water regime and the change in the quality of water as a result of the reduction of discharged wastewater into the surface waters, we chose the water flow through Zbýšov, HostěrádkyRešov and Újezd u Brna. In the past, the millrace was used to power mills, later for sewage disposal from surrounding villages. As a result, the bed is loaded with pollutant chemicals along with a high organic content and sediment. In spite of this considerable load, due to its natural self-cleaning ability, the millrace becomes a significant water and wetland biotope. This is significant in this area relatively poor in the natural occurrence of surface water.

In 2011 Povodí Moravy, s.p. at the request of Zbýšov, cleaned the inflow and the trough of the millrace for about $300 \mathrm{~m}$ up to the start of the village, thus renewing the flow in the millrace and restoring the original biocorridor. The water level of the small flowing channel has attracted aquatic animals such as the muskrat (Ondatra zibethicus), heron (Ardea cinerea), water insects (big bradawls and dragonflies (Libellula depressa) and amphibians. It also has ensured the growth of aquatic plants and the specific microclimate along the watercourse. At present, the millrace channel on the right bank of the Litava River near a solid weir is only clogged with waste to a slight degree. Both small hydropower plants on the millrace, which are located in the former mills, are inoperative. In times of increased rainfall, the original trough drains a portion of the floodwater from the sub-basin. The millrace also passes through the Hostěrádky-Rešov municipality. The bed of the millrace here is largely clogged with sewage and overgrown with bushes [11].

Prior to the construction of sewerage in the village, sewage and cesspools were connected to the millrace. In 2015 municipal sewage sewers were completed. The inhabitants were confessed to connect to this sewerage via the house's overflow shaft. In the same year the Šaratice wastewater treatment plant was put into operation, to which Zbýšov and Hostěrádka-Rešov are also connected. The rainwater drainage system remained in the village with open waterways in the millrace, but currently the race is only subsidized by rainwater. 
The research was focused on annual monitoring of water quality change in the millrace and reduction of flow rate due to the connection of households to the sewerage system [12].

The monitored area lies in the Litava River basin, which is the left-side tributary of the Svratka. The catchment area is $769.8 \mathrm{~km}^{2}$, the flow is $58.3 \mathrm{~km}$, and the average flow at the mouth is $1.53 \mathrm{~m}^{3} \cdot \mathrm{s}^{-1}$. The Litava flows mainly through intensive agriculture-managed landscapes. The river is situated at an altitude of $510 \mathrm{~m}$ northeast of the village of Cetechovice in the Zlín region. It flows from the west to the southwest direction, at the village of Židlochovice, at an altitude of $180 \mathrm{~m}$ asl, and it flows from the left to the Svratka in its river $\mathrm{km} \mathrm{29}$. The bed of Litava is modified along most of its length, both directionally and in its transverse profile. It is a trapezoid trough with levees above the surrounding terrain.

Approximately at $\mathrm{km} 18.6$ of the Litava River, a millrace turns off from the right bank near Zbýšov, originally used to feed the mill. On some maps this millrace is sometimes referred to as Mill Creek.

The total length of the race is about $5.7 \mathrm{~km}$ and it flows through Zbýšov and Hostěrádky-Rešov, and on the outskirts of Újezd u Brna it flows back again into the Litava. Small, unnamed and mostly seasonal watercourses also inflow to the millrace and, until recently, the sewerage outlet from adjacent municipalities [13].

\section{Materials and Methods}

Metering using a multiparameter meter $(\mathrm{pH}$, conductivity and dissolved oxygen) was chosen to assess the change in water quality of the millrace. These measurements were taken from December 2015 to December 2016. This span includes the period during which the inhabitants were gradually hooked up to the newly constructed sewerage network. The measurements were carried out regularly every month. These field measurements were supplemented by laboratory analyses of the samples taken. Water samples were taken with a periodicity of three months in December, March, June, September and December. A total of five sampling points was set: SP1 - Litava River, river $\mathrm{km} \mathrm{18.7,} \mathrm{before} \mathrm{the} \mathrm{millrace} \mathrm{turned} \mathrm{off.} \mathrm{The}$ second point of departure was the SP2 - the millrace, at river $\mathrm{km} 5.3$ per mill. SP3 - the millrace, river $\mathrm{km}$ 4.6, behind the village Zbýšov. SP4 - the millrace, river

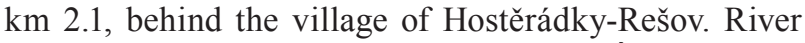
Litava SP5 river $\mathrm{km} \mathrm{13.9,} \mathrm{in} \mathrm{the} \mathrm{town} \mathrm{of} \mathrm{Újezd} \mathrm{u} \mathrm{Brna}$ was chosen by the last sampling profile (Fig. 1).

At each sampling profile, the $\mathrm{pH}$ and temperature were determined in the field using the portable HQ30d multi-parmeter meter and special INTELLI-CAL probes from the HACH LANGE Company, made in USA.

Water samples from streams were collected in December, March, June, September and December. The samples were then analyzed in the laboratory. The following indicators were determined: nitrate nitrogen, chemical oxygen demand (COD) and total phosphorus. Sample analyses were conducted in the laboratory of the Depatment of Applied and Landscape Ecology using a $\mathrm{HACH}$ thermoregulator and spectrophotometer.

Samples were processed in the Water Management Laboratory of the Department of Applied and Landscape Ecology of Mendel University in Brno. The analyses were performed by spectrophotometer DR/4000 from HACH LANGE Company, made in

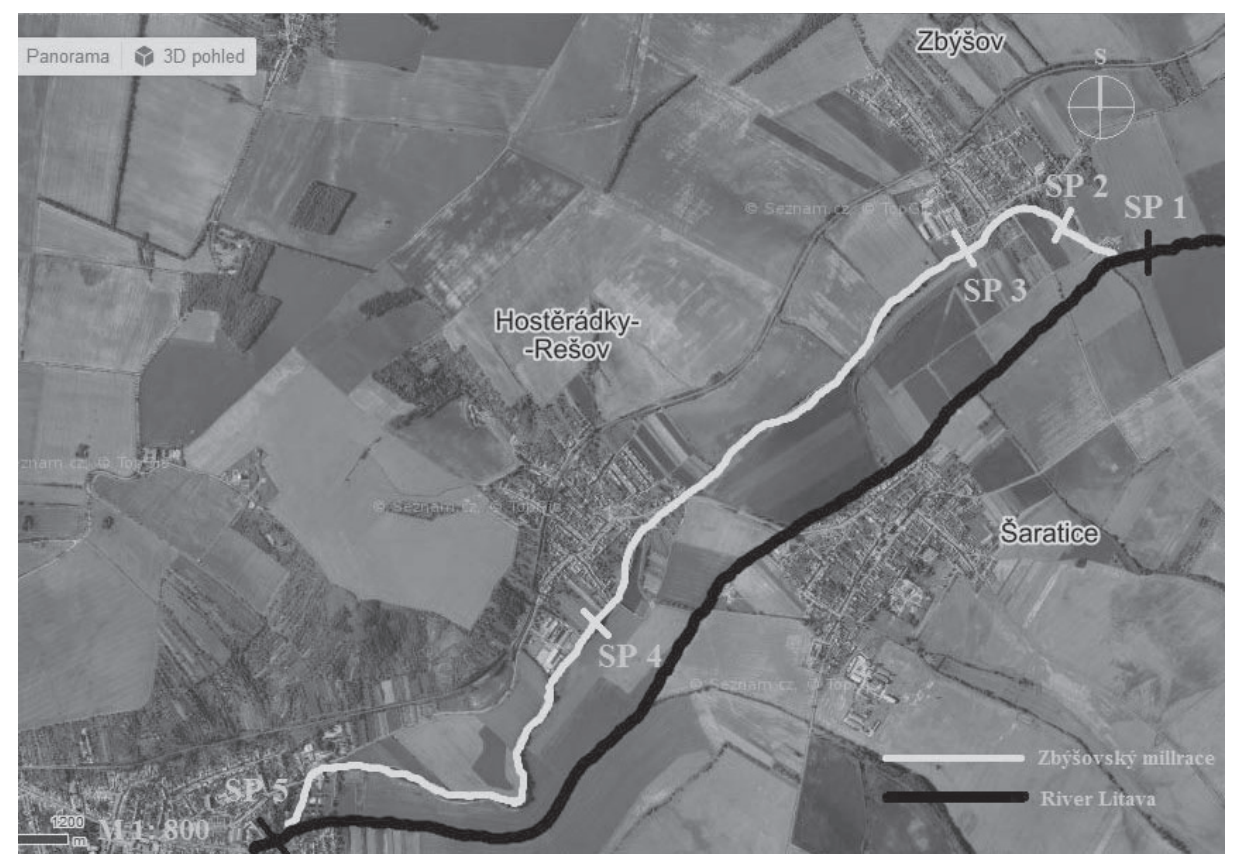

Fig. 1. Interest areas - sampling profiles (source: www.mapy.cz, edited by author). 
Table 1. Limit values of chosen indicators according to GD No. $401 / 2015 \mathrm{Sb}$.

\begin{tabular}{|c|c|c|}
\hline \multirow{2}{*}{ Indicator } & \multirow{2}{*}{ Units } & $\begin{array}{c}\text { Environmental quality stand- } \\
\text { ard (EQS) } \\
\text { GD No. 401/2015 Coll. }\end{array}$ \\
\cline { 3 - 3 } & & Average value \\
\hline $\mathrm{COD}_{\mathrm{Cr}}$ & $\mathrm{mgl^{-1 }}$ & 26 \\
\hline oxygen saturation & $\mathrm{mgl}^{-1}$ & $>9$ \\
\hline total phosphorus & $\mathrm{mgl}^{-1}$ & 0.15 \\
\hline $\mathrm{pH}$ & - & $5-9$ \\
\hline
\end{tabular}

USA. For determining total $\mathrm{P}, \mathrm{COD}_{\mathrm{Cr}}$ the samples are not filtered and had to be treated in the mineralization thermostat (total $\mathrm{P} 150^{\circ} \mathrm{C}, 30 \mathrm{~min} ; \mathrm{COD}_{\mathrm{Cr}}, 150^{\circ} \mathrm{C}$, $120 \mathrm{~min})$.

For determining the chosen indicators, nitrate nitrogen, the samples were filtered and subsequently treated according to the HACH LANGE manual. Laboratory work mainly consisted of the precise uptake (the control sample and the sample) and subsequent adding of reagents, then mixing, keeping of given time intervals and inserting samples into the spectrophotometer according to the Hach Lange method [14].

The results obtained were evaluated in compliance with Government Decree No. 401/2015 Sb., as amended to specify the Environmental Quality Standard (EQS; Table 1).

\section{Results and Discussion}

The $\mathrm{pH}$ value affects chemical and biological processes in water. Surface waters, apart from peat waters and acidified water reservoirs and lakes, have $\mathrm{pH}$ values ranging from 6.0 to 8.5 [15]. Annual measurements show a progressive increase in the $\mathrm{pH}$ segment in all measured profiles in the monitored section. The $\mathrm{pH}$ value stabilizes as neutral. Spring $\mathrm{pH}$ measurements show slightly alkaline values that are outside the EQS limit (min. value 5). These may be caused by increased supplements of discharged sewage into the millrace (Fig. 2).

Oxygen gets into the water either by diffusion from the atmosphere or by photosynthetic assimilation. Its water solubility is indirectly dependent on the temperature and the concentration of the solutes in the water. Government Decree No. 401/2015 Sb., as amended, specifies the EQS form oxygen saturation > $9 \mathrm{mg} .1$-1. From the graph (Fig. 3) it is evident that in profiles 2, 3, and 4 there is a lack of dissolved oxygen throughout the monitored period. This is likely to be due to the amount and composition of wastewater discharged into the millrace. At the end of the monitored period these values also correspond to the reduced flow rate due to the gradual connection of the population to the sewer systems in the municipalities.

Nitrates are found in almost all waters and are among the major anions. Their concentration in natural waters is increasing as a result of population growth and agricultural activity [15]. Nitrates are the ultimate product of the decomposition of nitrogenous substances of organic origin under aerobic conditions. The nitrate content of surface waters is related to the degree of eutrophication and is one of the specific indicators of the chemical composition of surface water [16].

Nitrate nitrogen is in the area of interest that oscillates around the limit of EQS (5.4 $\left.\mathrm{mg}^{-1} \mathrm{~N}^{-1} \mathrm{NO}_{3}^{-}\right)$. Profiles 1 and 5 are located in the Litava stream and are defacto control for Profiles 2, 3 and 4. These vary greatly during tracking. The second and third profiles from the second half of 2016 show comparable results; on the contrary, profile 4 shows the highest nitrate nitrogen values in September 2016 (Fig. 4). This value progression of nitrate nitrogen occurring in the millrace can be due to a more active connecting of households to the sewage system in the village of Zbýšov than in Hostěrádky-Rašov, which is evident from profile 4.

Furthermore, the concentrations of ${\mathrm{N}-\mathrm{NO}_{3}}^{-}$ correspond to the total flow rate of the water in the millrace, which since mid-summer has been subsidized by total lower precipitation.

In natural waters and wastewater, phosphorus occurs predominantly in the form of different phosphates. The $\mathrm{pH}$ of water [17] is determined by whether inorganic orthophosphates take the forms of $\mathrm{PO}_{4}^{3-}, \mathrm{HPO}_{4}^{2}$, $\mathrm{H}_{2} \mathrm{PO}_{4}^{-}$or $\mathrm{H}_{3} \mathrm{PO}_{4}$. Total phosphorus is determined

Table 2. Limit values of chosen indicators according to Czech standard ČSN 757221.

\begin{tabular}{|c|c|c|c|c|c|c|}
\hline \multirow[t]{2}{*}{ Indicator } & \multirow[t]{2}{*}{ Units } & \multicolumn{5}{|c|}{$\begin{array}{c}\text { Class } \\
\text { Czech standard ČSN } 757221 \\
\end{array}$} \\
\hline & & I & II & III & IV & V \\
\hline Conductivity & $\mathrm{mS} \cdot \mathrm{m}^{-1}$ & $<40$ & $<70$ & $<110$ & $<160$ & $\geq 160$ \\
\hline Oxygen saturation & $\mathrm{mg} \cdot \mathrm{l}^{-1}$ & $>7.5$ & $>6.5$ & $>5$ & $>3$ & $\leq 3$ \\
\hline $\mathrm{COD}_{\mathrm{Cr}}$ & $\mathrm{mg} \cdot \mathrm{l}^{-1}$ & $<15$ & $<25$ & $<45$ & $<60$ & $\geq 60$ \\
\hline Nitrate nitrogen & $m g \cdot 1^{-1}$ & $<3$ & $<6$ & $<10$ & $<13$ & $\geq 13$ \\
\hline Total P & $\mathrm{mg} \cdot \mathrm{l}^{-1}$ & $<0.05$ & $<0.15$ & $<0.4$ & $<1$ & $\geq 1$ \\
\hline
\end{tabular}


by the amount of inorganic orthophosphate $\left(\mathrm{PO}_{4}^{3-}\right)$, polyphosphates and organically bound phosphorus. Phosphorus is obtained in the form of orthophosphates and polyphosphates from fertilizers, washing and cleaning agents, etc. Organically bound phosphorus is derived from decomposition products of fauna and flora and animal waste, but also from chemical preparations used in agriculture. During the observed period, overall phosphorus was above the limit values compared to the environmental quality standard $\left(0.15 \mathrm{mgl}^{-1}\right)$.

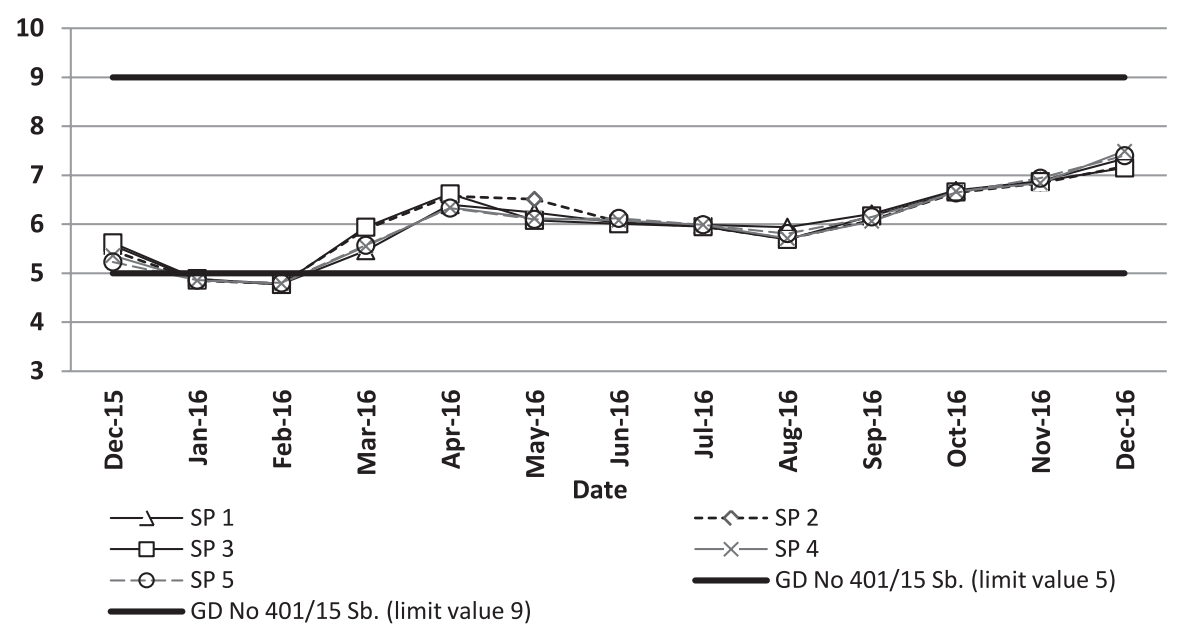

Fig. 2. $\mathrm{pH}$ course.

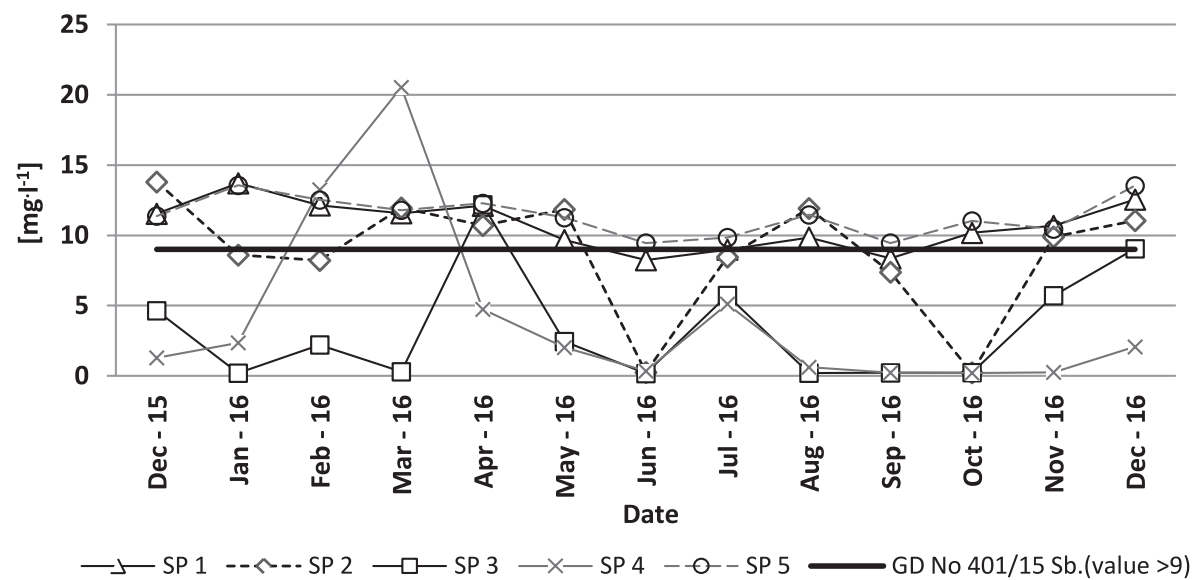

Fig. 3. Course of dissolved oxygen.

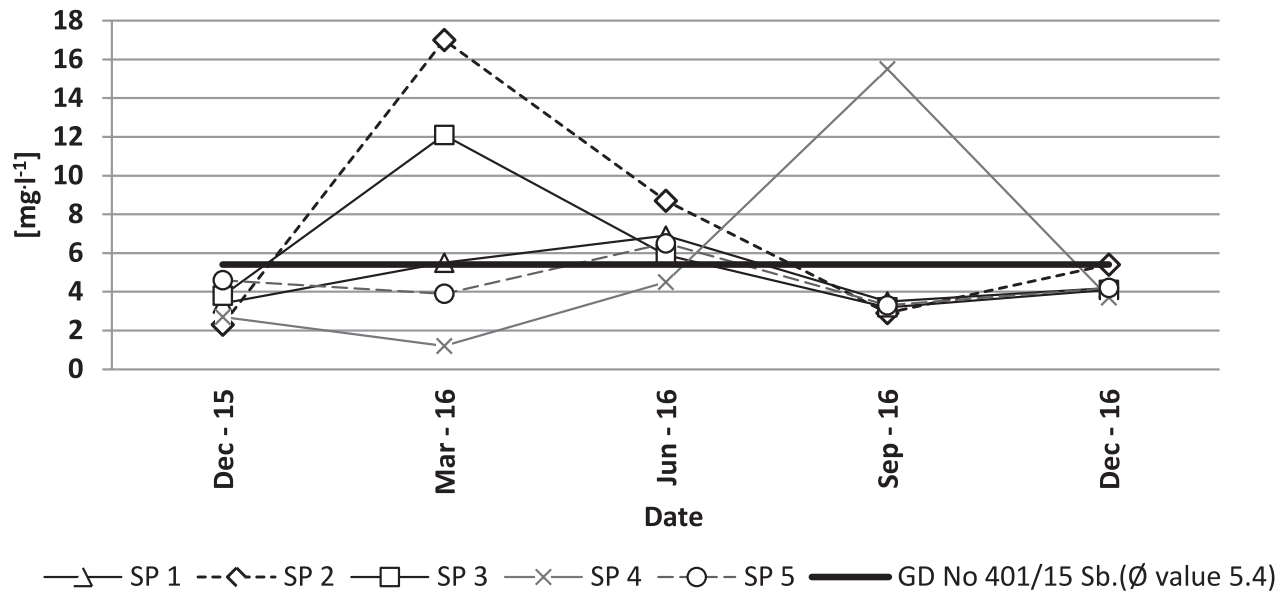

Fig. 4. Course of nitrate nitrogen concentrations. 


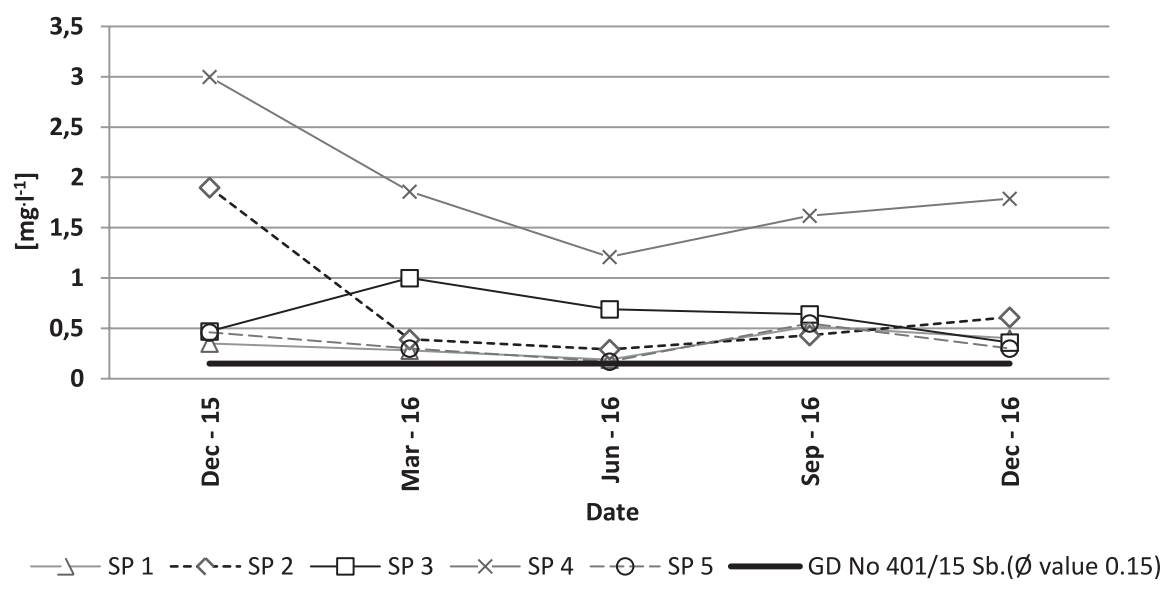

Fig. 5. Course of total phosphorus concentrations.

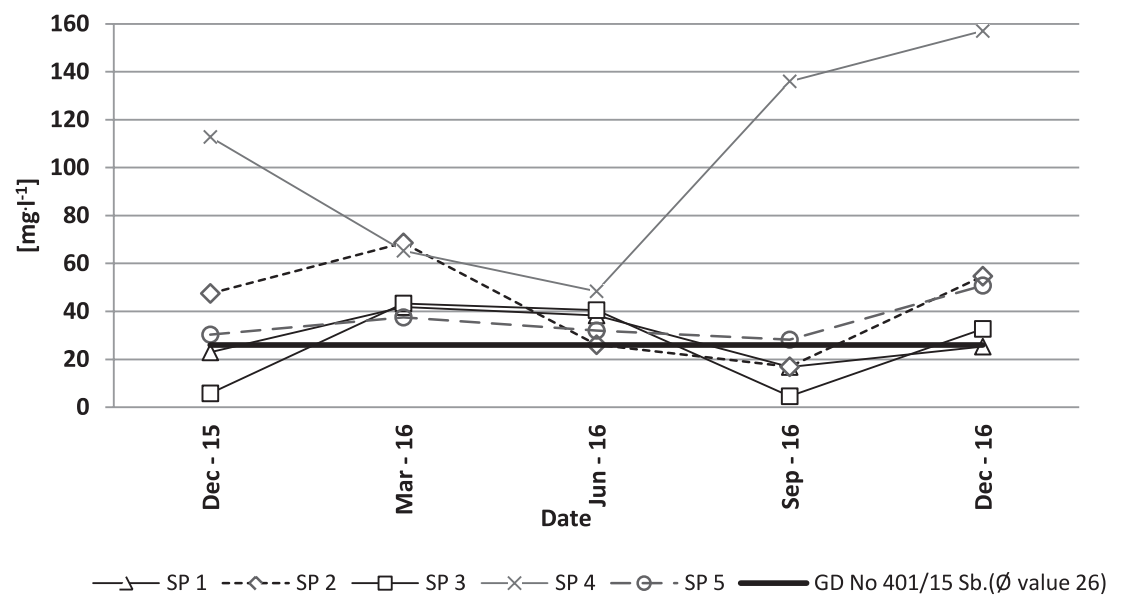

Fig. 6. Course of COD concentrations.

For profile 4, this is even more than a multiple of this limit. The presence of municipal wastewater is again the main reason for these over-limit values.

Chemical oxygen demand (COD) is a comprehensive indicator of all organic pollution, regardless of whether it is a biodegradable substance or not. Chemical oxygen demand is defined as the amount of oxygen corresponding to the consumption of the oxidizing agent in the complete oxidation of the organic substances contained in the water [18, 19]. Potassium dichromate $\left(\mathrm{K}_{2} \mathrm{Cr}_{2} \mathrm{O}_{7}\right)$ is used as an oxidizing agent, and we are talking about chemical oxygen consumption by the dichromate method $\left(\mathrm{CHSK}_{\mathrm{Cr}}\right)$. COD denotes organic water pollution. The results show that profile 4 exceeds by many times the EQS limit ( $\varnothing$ value $26 \mathrm{ml}^{-1} \mathrm{l}^{-1}$ ) (Fig. 6). In other profiles, CHSK values are also exceeded in some cases due to the discharge of large amounts of wastewater into the flow.

Over the last 25 years, water quality has improved significantly, but there are still (though only short) stretches of watercourses classified in the $5^{\text {th }}$ class of surface water quality. According to the basic classification, most water courses fall into Class III. - contaminated water. However, compared to the two-year period 2014-2015, water quality has also improved in some stretches of larger flows in Class II. slightly polluted water [20].

The water quality assessment in the mill stream corresponds to Czech standard 757221 with the Report on the State of Water Management of the Czech Republic in 2016. Specific profiles SP2, SP3 and SP4 fall under the indicators: dissolved oxygen up to the $3^{\text {rd }}-5^{\text {th }}$ grades, total phosphorus to $3^{\text {rd }}-5^{\text {th }}$ grades, COD SP4 $-5^{\text {th }}$ grade and SP2-SP3 profiles to the $3^{\text {rd }}$-grade quality. Concentration of nitrate nitrogen is in class 4 (Table 2).

In the comprehensive comparison of the monitored indicators it can be said that after gradually connecting the households to the sewerage system, some of the indicators approach the limit values that are anchored in the legislation of the Czech Republic (GD No. 401/15 Sb.). These are mainly $\mathrm{pH}$ indicators. It is also evident that profiles 2 and 3 show a positive development in terms of total phosphorus and nitrate nitrogen concentrations. In the sampling profile 4, the indicators of dissolved oxygen, COD, total phosphorus and nitrate nitrogen show that households in Hostěrádky-Rešov are connecting to the sewerage system at a slower pace than 
in Zbýšov. In this village, there is visible improvement in the concentration of all indicators.

Agriculture is recognized as one of the branches of the economy that has led to major problems in water environments, such as eutrophication and ecosystem damage. In European Union countries, various measures have been introduced as part of catchment basin management planning as a means of tackling problems of diffuse pollution from agriculture [2]. Nevertheless, we can also assume that the above-limit concentration of almost all indicators is partly related to the use of land in the monitored area, which is used exclusively for agricultural activity.

Nitric applied to croplands has been blamed as the major source of $\mathrm{N}$ in surface water in the agricultural watershed [22]. For example, Zhao et al. [22] showed that the the largest source of $\mathrm{N}$ load in the surface water of LRW was rural human and livestock excreta, accounting for $43.3 \%$ of the total load. The plant nutrients and soil material eroded from the fields contribute to water eutrophication [23].

Unfortunately, there is also a second observation factor, which is the change in the flow rate of water in the millrace. The connection of households to WWTPS gradually reduces the flow rate and consequently reduces the self-cleaning capacity of the flow in the millrace, because the flow is only dependent on the supplement from the precipitation water, which mostly decreases in the summer months. This results in complete draining of the feeds into the mill stream, and the subsequent drying of the millrace itself. During the year's tracking, the watercourse was shortened by almost $100 \mathrm{~m}$, which is a very alarming finding.

\section{Conclusions}

The objective of this paper was to monitor the change of water quality and flow while changing the flow rate in the stream due to the construction of sewer neighbouring villages Zbýšov a Hostěrádky -Rešov. Sewage is now held at the newly built sewers and sewage treatment plant water flow, as in the past, man-made millrace, is now supplemented only by precipitation totals. The monitoring took place immediately after the call to connect the households to the sewerage system. Five profiles were monitored - the $1^{\text {st }}$ and $5^{\text {th }}$ profiles were selected on the Litava River, before the turn of the millrace and after the drifting back to Litava and served as control. Measurement profiles 2, 3 and 4 were selected directly in the millrace so that we could monitor the influence of the two municipalities on changes in it. The measured and analyzed samples were subsequently compared with GD No 401/15 Sb. and with Czech standard 75 7221. After one year of monitoring and analyzing samples of water from the flume it can be stated that the quality of water shows improvement in the selected indicators of $\mathrm{pH}$, as well as persisting over limit values for particular parameters: total phosphorus, nitrate nitrogen, and dissolved oxygen COD. Although the water is discharged from sewage water, the contaminated water remains in the flume. The water is less frequent, and the water flow is shortened by about $100 \mathrm{~m}$ during the year. It is now necessary to focus more closely on the management of the surrounding plots of land in the catchment area, where agriculture is predominantly undertaken on private lands. It can be the biggest polluter of the current [24]. As mentioned in the paper, this flow becomes a significant water and wetland biotope. This is in an area where natural surface waters are mostly lacking. That is why it would be advisable to pay more attention in the future, not only in the form of further monitoring of water quality but also in the creation of a new wetland.

In the context of climate change, we will now continue to face similar challenges. The situation described in this article is triggered by the new legislation of the Czech Republic, which reduces the discharge of polluted waters into surface waters. A similar situation occurs also due to dry years, when there is a minimal inflow of surface water from precipitation and a significant source is then purified wastewater from built-up areas. The law in the Czech Republic to EU legislation and, in the other member states is addressed the issue of discharge of urban wastewater into surface water and their impact on water flows [25]. It must be paid to the modeling of various scenarios for determining the behavior of aquatic habitats in response to low flow rates [26].

\section{Acknowledgements}

This study was supported by the grant APVV16-0278: the use of hydromelioration structures for mitigating the negative extreme hydrological phenomena effects and their impacts on the quality of water bodies in agricultural landscapes by the Slovak Research and Development Agency.

\section{Conflict of Interest}

The authors declares no conflict of interest.

\section{References}

1. Czech standard ČSN 75 7221. Water quality - Classification of surface water quality. Prague: Czech Standards Institute, 12, Praha, CZ, 1998.

2. KÖSE E., TOKATLI C., ÇIÇEK A. Monitoring Stream Water Quality: A Statistical Evaluation. Pol. J. Environ. Stud. 23, 1637, 2014.

3. STANISZEWSKI R., JUSIK S., BOROWIAK K., BYKOWSKI J., DAWSON F.H., Temporal and Spatial Variations of Trophic Status of a Small Lowland River, Pol. J. Environ. Stud. 28 (1), 329, 2019. 
4. SOBOLEWSKI W., Effect of Agricultural Land Use on the Water Quality of Polish Lakes: a Regional Approach, Pol. J. Environ. Stud. 25 (6), 2705, 2016.

5. Development Strategy of the South Moravian Region 2020. Available at: https://m.kr jihomoravsky.cz/Default. aspx?PubID=175435\&TypeID=2, (accessed on 15/07/2018)

6. Act No. 254/2001 Sb., On Water and on Amendments to Certain Acts (Water Act), as amended, 2018.

7. Decree No. 501/2006 Sb., On General Requirements for Landuse, 2018.

8. Act No. 183/2006 Sb., On Spatial Planning and Building Regulations (Building Act), as amended, 2018.

9. THELLMANN P., KUCH B., WURM K., KOHLER H.R., TRIEBSKORN R. Water quality assessment in the "German River of the years 2014/2015": how a case study on the impact of a storm water sedimentation basin displayed impairment of fish health in the Argen River (Southern Germany) By:, ENVIRONMENTAL SCIENCES EUROPE; DOI: 10.1186/s12302-017-0108-y; 2017.

10. ZELENAKOVA M., PURCZ P., HARBULAKOVA V.O., ORAVCOVÁ. A. Determination of pollutant concentrations in the Krasny Brod River profile based on the Buckingham theorem, Conference: $2^{\text {nd }}$ International Conference on Recycling and Reuse Location: Istanbul, TURKEY Date: JUN 04-06, 2014 DESALINATION AND WATER TREATMENT 57 (6) Special Issue: SI 2693, 2016.

11. GERNEŠOVÁ L. Study changes in water quality on Zbýšov millrace, Bachelor thesis MENDELU in BRNO, CZ, 74, 2017.

12. Litava. WWTP Šaratice-Zbýšov-Hostěrádky-Rešov: Information on the construction process and WWTP and sewerage system. Available online: http://www.litavadso.cz/stavba/informace-o-postupu-vystavby-cov-akanalizace/ (accessed on 15/03/2017)

13. Heis. Hydro-ecological information system VÚV TGM. Available online: http://heis.vuv.cz (accessed on 27/03/2017)

14. HUBAČÍKOVÁ V., OPPELTOVÁ P. The impact of pond on water quality in the Čermná stream, J. Ecol. Eng. 18 (1), 2017.
15. PITTER P. Hydrochemistry 4. VŠCHT Praha, CZ, 592, 2009.

16. HORÁKOVÁ M., LISCHKE P., GRUNWALD A. Chemical and physical methods of water analysis. 2. Praha, CZ, pp 389, 1989.

17. LELLÁK J., KUBÍČEK F. Hydrobiology. 1. Praha: Karolinum, CZ, 257, 1992

18. POŠTA J., HEJTMÁNKOVÁ A., JUST T., RŮŽIČKOVÁ I., KOLLER J., DOHANYOS M. Wastewater treatment plants, ČZU Praha, CZ, 208, 2005.

19. VYRIDES I., STUCKEY D. C. A modified method for the determination of chemical oxygen demand (COD) for samples with high salinity and low organics. Bioresource Technology. 100. 979, 2009.

20. POKORNÝ D., FOUSOVÁ E., HUBALOVÁ P., Report on Water Management in the Czech Republic in 2016, Ministry of Agriculture of the Czech Republic, Praha, CZ, 127, 2017.

21. DUNN S.M., SAMPLE J., POTTS J., ABEL C., COOK Y., TAYLOR C., VINTEN A.J.A. Recent trends in water quality in an agricultural catchment in Eastern Scotland: elucidating the roles of hydrology and land use. Environ. Sci. Process., 16 (2), 1659, 10.1039/C3EM00698K, 2014.

22. ZHAO Y., JIANGL L., WUL Y. Nitrogen Budget and Surface Water Nitrogen Load in a hinese Watershed, Pol. J. Environ. Stud. 27 (3), 1387, 2018.

23. MAZUR A. Surface and Subsurface Water Runoff and Selected Matter Components From the Forested Loess Slope, Journal of Ecological Engineering 19 (6), 259, 2018.

24. LIPCZYNSKA-KOCHANY E. Effect of climate change on humic substances and associated impacts on the quality of surface water and groundwater: Science of the total environment, 640, 1548, 2018.

25. SAKSON G., BRZEZINSKA A., ZAWILSKI M., Prospects for reduction of the impact of wastewater discharge from urban areas on surface water quality in view of legal regulations. Ochrona srodowiska 39, 27, 2017.

26. ANTUNES I.M.H.R., ALBUQUERQUE M.T.D., OLIVEIRA S.F., Predictive scenarios for surface water quality simulation - A watershed case study, Catena 170, 283, 2018. 